J. Clin. Chem. Clin. Biochem.

Vol. 20, 1982, pp. 69-74

\title{
Determination of Acetylcholinesterase and Pseudocholinesterase in Gastrointestinal Biopsy Tissue
}

\author{
By W. E. Hansen and S. Bertl
}

\section{Medizinische Klinik rechts der Isar der Technischen Universität München}

(Received June 23/September 30, 1981)

Summary: An optimized micromethod for the determination of soluble acetylcholinesterase and pseudocholinesterase in gastrointestinal biopsy tissue is introduced. Enzyme activities were obtained from measurements of total activity and activity in the presence of an inhibitor of pseudocholinesterase. Optimal conditions of measurement were established for enzymes in serum or erythrocytes. In intestinal tissue, measurements were precise and reproducible. Interference by blood contained in the biopsy specimens were found to be neglegible. Also drugs used for premedication had no significant influence. Finally, results from normal stomach, duodenum and colon are presented.

The use of cholinesterase determinations in physiological studies and the diagnosis of M. Hirschsprung are discussed.

\section{Die Bestimmung der Acetylcholinesterase und Pseudocholinesterase in Biopsiegewebe aus dem Magen-Darm-Trakt}

Zusammenfassung: Eine optimierte Mikromethode für die Bestimmung der löslichen Acetylcholinesterase und Pseudocholinesterase in gastrointestinalem Biopsiegewebe wird vorgestellt. Die Enzymaktivitäten wurden aus Messungen der Gesamtaktivität und der Restaktivität in Gegenwart eines Inhibitors ermittelt. Optimale Meßbedingungen wurden für die Enzyme im Serum und in Erythrocyten entwickelt. In Schleimhautproben erwiesen sich die Messungen als präzise und reproduzierbar. Störungen durch Blut in den Schleimhautproben waren zu vernächlässigen, ebenso Störungen von den für die Prämedikation verwendeten Medikamenten. Abschließend werden Meßergebnisse von normaler Magen-, Duodenal- und Colonschleimhaut mitgeteilt.

Anwendungsmöglichkeiten der Cholinesterasebestimmungen sind physiologische Studien sowie die Diagnose des M. Hirschsprung.

\section{Introduction}

Cholinesterases may be found in relatively high activities in gastrointestinal tissues. By histochemical techniques two enzymes have been differentiated, namely acetylcholinesterase (EC 3.1.1.7) and pseudocholinesterase (EC 3.1.1.8) (1). In animal studies, distribution of the enzymes was different: both were contained in the ganglia and in the connecting fiber tracts of the myenteric and submucous plexuses; acetylcholinesterase was found alone in certain epithelial cells and muscle fibres of the villi, as well as in the circular muscle; pseudocholinesterase was present almost exclusively in the longitudinal muscle, in the muscularis mucosae and in argyrophil cells $(1,2)$. In clinical medicine Hirschsprung's disease has attracted some attention. In it aganglionic intestinal tissue causes obstruction (3). Diagnosis usually is made from radiological findings, manometry and histochemistry of cholinesterases (4). Recently a biochemical assay of acetylcholinessterase and pseudocholinesterase was used for the diagnosis (5). As in histochemical studies both the enzymes were differentiated by using an inhibitor of pseudocholinesterase, a technique that had been suggested by Augustinsson $(6,7)$. We report here an optimized method for the biochemical determination of both the enzymes which allows measurements in 2-3 biopsy particles obtained during routine endoscopy. As an inhibitor of pseudocholinesterase, lysivane (10-( $\alpha$-diethylaminopropyl)phenothiazine) was used. Enzyme measurements are based on the following equations $(8,9)$ : 


\section{(1) Acetylthiocholine $+\mathrm{H}_{2} \mathrm{O}$ \\ cholinesterase \\ thiocholine + acetic acid}

(2) thiocholine $+5,5$-dithiobis-(2-nitrobenzoic acid) $\rightarrow$ 5-mercapto-2-nitrobenzoic acid + (2-N-trimethylamino)ethyl-(3-carboxy-4-nitro)phenyl disulfide.

The product 5-mercapto-2-nitrobenzoic acid is a yellow compound. Its formation is followed photometrically. For the development of the method studies were also performed in human serum, which contains pseudocholinesterase, and in erythrocytes with high activities of acetylcholinesterase.

\section{Materials and Methods \\ Preparation of tissue samples \\ Tissue specimens were obtained during routine endoscopy by forceps biopsy. By histological examination they were classified as "normal". Patients gave written, informed consent. For ex- periments which required numerous samples mucosal tissue of larger specimens removed at operations was used. The assay could be performed satisfactorily in 2-3 particles weighing $10-15 \mathrm{mg}$. The specimens were placed in $4 \mathrm{ml} 0.1 \mathrm{~mol} / 1$ phos- phate buffer, $\mathrm{pH}$ 8.0. They could be kept refrigerated at $4{ }^{\circ} \mathrm{C}$ for at least 2 days without loss of activity. For assay, biopsy particles were homogenized at $0^{\circ} \mathrm{C}$ in a motor-driven Potter- Elvehjem homogenizer at $1100 \mathrm{~min}^{-1}$ for $3 \mathrm{~min}$. Then the homo- genate was centrifuged for $10 \mathrm{~min}$ at $5000 \mathrm{~g}$. Assays of enzymes and protein were performed in the supernatant. \\ Blood was drawn from healthy volunteers. Erythrocytes were obtained from samples with EDTA as an anticoagulant. They were washed 5 times with saline and finally resuspended in distilled water for haemolysis. Assays were performed after $1: 200$ or $1: 2000$ dilution with $0.1 \mathrm{~mol} / 1$ phosphate buffer, pH 8.0.}

Determination of cholinesterases

For practical purposes the following solutions were prepared: $0.1 \mathrm{~mol} / 1$ phosphate buffer $\mathrm{pH} 6.7, \mathrm{pH} 7.0, \mathrm{pH} 8.0$ (from potassium dihydrogen phosphate and disodium hydrogen phosphate according to standard procedures).

\section{Color reagent}

$39.64 \mathrm{mg}$ 5,5-dithiobis-(2-nitrobenzoic acid), (Boehringer Mannheim, Mannheim, FRG) and $15 \mathrm{mg}$ sodium hydrogen carbonate were dissolved in $10 \mathrm{ml} 0.1 \mathrm{~mol} / 1$ phosphate buffer, $\mathrm{pH} 7.0$. This solution is stable for 1 week (9).

\section{Substrate}

$21.69 \mathrm{mg}$ acetylthiocholine iodide (Boehringer Mannheim, Mannheim, FRG) was added to $4.95 \mathrm{ml}$ distilled water followed by $0.05 \mathrm{ml} 1 \mathrm{~mol} / 1$ hydrochloric acid to decrease non enzymic hydrolysis. This solution is stable at $4{ }^{\circ} \mathrm{C}$ for several weeks (10).

\section{Pseudocholinesterase inhibitor}

$27.64 \mathrm{mg}$ lysivane (kind gift from Rhone-Poulenc, Paris, France) were dissolved in $30 \mathrm{ml} 2 \mathrm{~mol} / 1$ hydrochloric acid and made up to $100 \mathrm{ml}$ with $0.1 \mathrm{~mol} / 1$ phosphate buffer, $\mathrm{pH}$ 7.0. This solution is stable at $4^{\circ} \mathrm{C}$ for several weeks (5). Some experiments were also carried out with "Astra 1397" (kind gift of Astra $\mathbf{A B}$, Wedel, FRG), atropine, butylscopolamine (Boehringer Ingelheim, Ingelheim, FRG), diazepam (Hoffmann-La Roche, Grenzach, FRG), pethidine, levallorphan (both Hoechst, Frankfurt, FRG), and triflupromazine (Heyden, Munich, FRG).
All reagents were analytical grade and if not stated otherwise obtained from E. Merck, Darmstadt, FRG.

\section{Procedure}

For determination of total cholinesterase activity $2 \mathrm{ml}$ color reagent solution were mixed with $14 \mathrm{ml} 0.1 \mathrm{~mol} / 1$ phosphate buffer $\mathrm{pH}$ 6.7. Acetylcholinesterase was measured in the presence of lysivane: $2 \mathrm{ml}$ color reagent solution and $1 \mathrm{ml}$ lysivane solution were added to $13 \mathrm{ml} 0.1 \mathrm{~mol} / 1$ phosphate buffer $\mathrm{pH} 8.0$. For enzyme assay $0.2 \mathrm{ml}$ were mixed with $0.5 \mathrm{mi}$ sample solution in microcuvettes. After 15 min preincubation the reaction was started by the addition of $0.05 \mathrm{ml}$ substrate solution. Concentrations in the cuvette were as follows:

$333 \mu \mathrm{mol} / 1$ 5,5-dithiobis-(2-nitrobenzoic acid), $1 \mathrm{mmol} / \mathrm{l}$ acetylthiocholine iodide, $13.2 \mu \mathrm{mol} / \mathrm{l}$ lysivane; the $\mathrm{pH}$ was 7.4 .

The reaction was followed in a photometer with attachments for semiautomatic enzyme measurements (Eppendorf Gerätebau, Hamburg, FRG; models $1101 \mathrm{M}$ (photometer), 6452 (enzyme calculator), 6522 (printer)). The temperature was kept constant at $25^{\circ} \mathrm{C}$. The wave length was $405 \mathrm{~nm}$, and the light-path in the cuvette $1 \mathrm{~cm}$. The molar lineic absorbance of 5 -mercapto-2-nitrobenzoic acid at $405 \mathrm{~nm}$ is $1330 \mathrm{~m}^{2} \times \mathrm{mol}^{-1}$ $\left(13.3 \times 10^{3} 1 \times \mathrm{mol}^{-1} \times \mathrm{cm}^{-1}\right)(10)$. Measurements were per:formed in triplicate. (If little specimen material is available determinations can also be carried out in duplicate. Homogenization should then be performed in $3 \mathrm{ml}$ buffer solution:) If 6 cuvettes were measured automatically once every minute, the factor for calculation of enzyme activity (U/1) was 40.26 . For the determination of spontaneous hydrolysis of acetylthiocholine iodide, measurements were also performed with buffer instead of sample solution. If necessary this reading was subtracted from the enzyme activities.

Activity of pseudocholinesterase was calculated as the differience between total cholinesterase activity and acetylcholinesterase activity.

Protein concentration in the supernatant was determined according to Lowry et al (11).

Statistical calculations were performed on a Hewlett-Packard 97 computer. Results are expressed as the mean \pm standard deviation.

\section{Results and Discussion}

If the enzyme reaction was started by adding acetylthiocholine iodide there was an immediate increase in absorption. The kinetics followed almost żero order.

\section{Studies in human erythrocytes and serum}

In order to establish optimal conditions of measurement investigations were performed in erythrocytes, which contain acetylcholinesterase, and in serum, which contains pseudocholinesterase.

\section{Influence of inhibitors on acetylcholinesterase and pseudocholinesterase}

In order to study the effects of inhibitors, pseudocholinesterase activity in serum was measured in the presence of various concentrations of lysivane. Inhibition was proportional to lysivane concentration (fig. 1). If acetylcholinesterase in erythrocytes was studied in the 


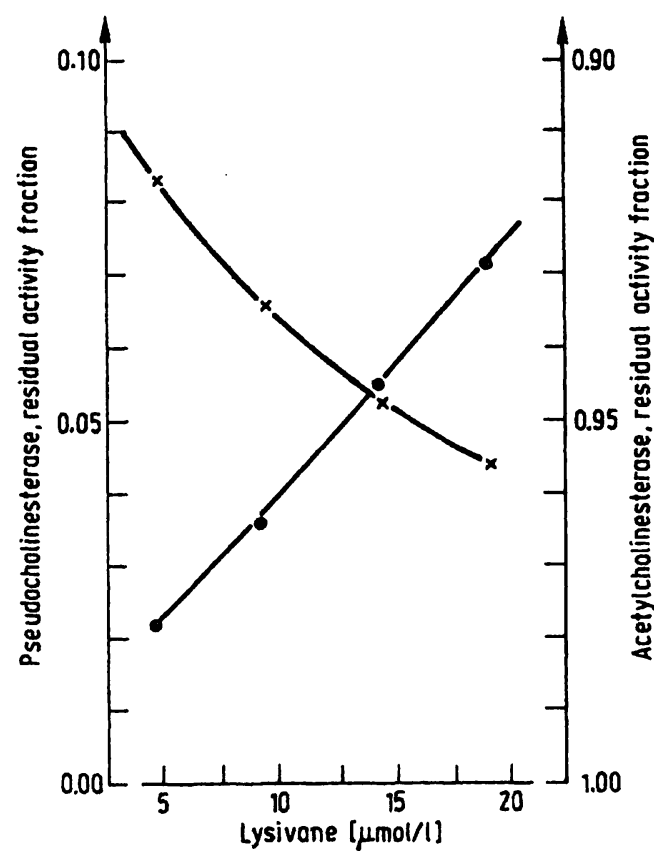

Fig. 1. Inhibition of plasma pseudocholinesterase $(x-x)$ and erythrocyte acetylcholinesterase $(0-0)$ by increasing concentrations of lysivane. Results from 4 experiments. For assay of acetylcholinesterase in the presence of pseudocholinesterase a concentration of $13.2 \mu \mathrm{mol} / 1$ lysivane was chosen.

same way, there was only a small decrease in activity. $13.2 \mu \mathrm{mol} / \mathrm{l}$ lysivane was found to be the optimal concentration, because there was a maximal inhibition of pseudocholinesterase $(94.6 \%)$ and only minimal inhibition of acetylcholinesterase (5.4\%) (fig. 1). Similar findings were also reported by Dale et al. who found 14.2 $\mu \mathrm{mol} / 1$ to be the optimal inhibitor concentration (5). When Astra 1397, which is structurally related to lysivane, was investigated in a similar way, the "optimal concentration" was $44.5 \mu \mathrm{mol} / 1$. A similar effect had been reported previously, the concentration recommended for inhibition of pseudocholinesterase, however, was $165 \mu \mathrm{mol} / 1$, which is almost 4 times higher (6). We decided to employ lysivane as an inhibitor.

\section{Influence of $\mathrm{pH}$ value on enzyme activities}

There was a strong influence of $\mathrm{pH}$ value on activities of acetylcholinesterase and pseudocholinesterase (fig. 2). In order to keep non-enzymic hydrolysis of acetylthiocholine iodide low, it has been recommended that measurements be performed at $\mathrm{pH}$ values below 7.8 (19). In our assays the $\mathrm{pH}$ therefore was adjusted to 7.4 .

Studies on human gastrointestinal biopsy tissue Influence of concentrations of the substrate and the color reagent on enzyme activities

If the concentrations of acetylthiocholine iodide are increased enhancement of non-enzymic hydrolysis occurs

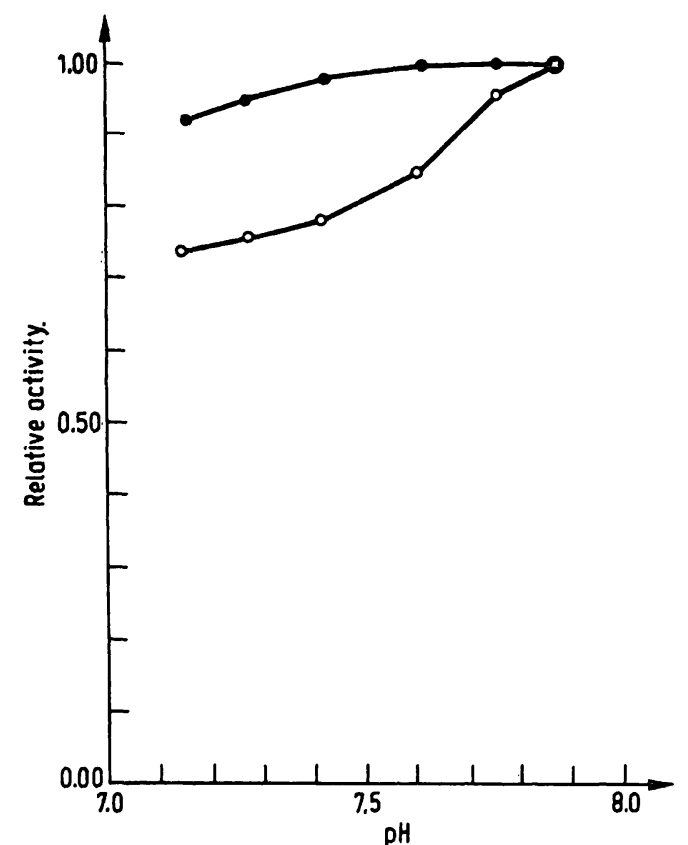

Fig. 2. Influence of $\mathrm{pH}$ on relative activity of erythrocyte acetylcholinesterase (-०) and serum pseudocholinesterase $(0-0)$. Results from 4 experiments. Activities at $\mathrm{pH}$ 7.87 were taken as 1.00 . In order to keep non-enzymic hydrolysis of acetylthiocholine low, assays were carried out at pi 7.4.

(9). Also there is considerable inhibition of product . formation at concentrations beyond $10^{-3} \mathrm{~mol} / \mathrm{l}(9)$. In order to further establish optimal conditions of measurement, various concentrations of acetylthiocholine iodide were tested in the same sample. Results from a typical experiment are given in figure 3. Clearly the enzyme was inhibited at concentrations higher than

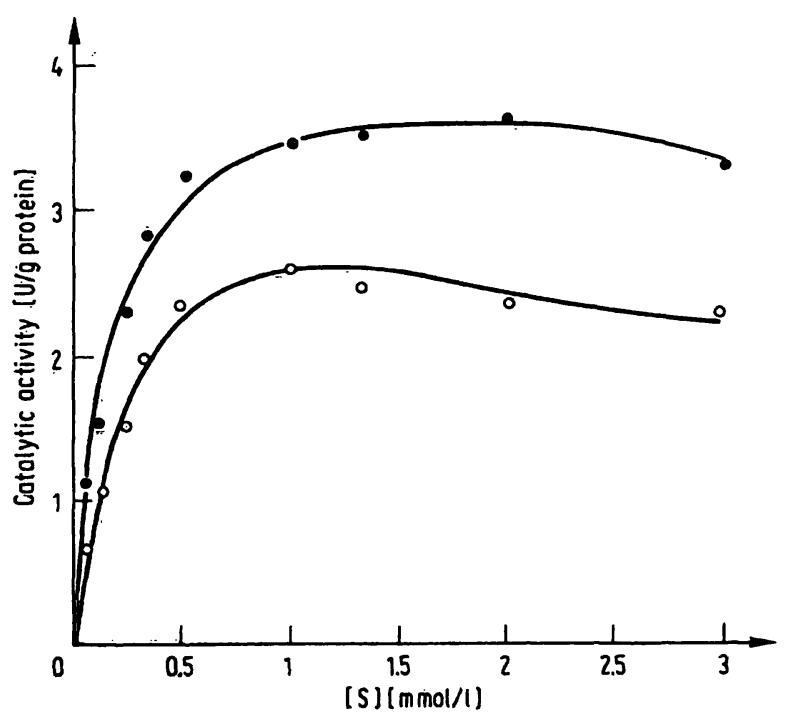

Fig. 3. Influence of substrate concentration on total cholinesterase catalytic activity $(\bullet-\bullet)$ and acetylcholinesterase catalytic activity $(0-0)$ from human colonic mucosal tissue. in order to avoid disturbances from nonenzymic hydrolysis and from inhibition of product formation by the substrate a concentration of $10^{-3}$ $\mathrm{mol} / \mathrm{l}$ acetylthiocholine iodide was chosen. 
$2 \times 10^{-3} \mathrm{~mol} / 1$ acetylthiocholine iodide. We therefore decided to carry out our tests at $10^{-3} \mathrm{~mol} / \mathrm{l}$ acetylthiocholine iodide. This is higher than the concentrations that were previously reported for measurements in tissue homogenates, which ranged between $47 \mu \mathrm{mol} / 1$ (9) and $500 \mu \mathrm{mol} / 1$ (5).

In a similar manner various concentrations of the color reagent were investigated. There was no influence on the enzyme activities over a range between $33 \mu \mathrm{mol} / \mathrm{l}$ and $660 \mu \mathrm{mol} / 1$ 5,5-dithiobis-(2-nitrobenzoic acid). In the tests a concentration of $330 \mu \mathrm{mol} / 1$ 5,5-dithiobis-(2-nitrobenzoic acid) was used.

\section{Calibration curve}

The calibration curve was constructed by diluting the supernatant of human colonic mucosal homogenate with various quantities of $0.1 \mathrm{~mol} / 1$ phosphate buffer, $\mathrm{pH}$ 8.0. There was a linear relationship between the concentrations of enzyme and measured enzyme activities (fig. 4). This finding was true for total cholinesteräse as well as for acetylcholinesterase.

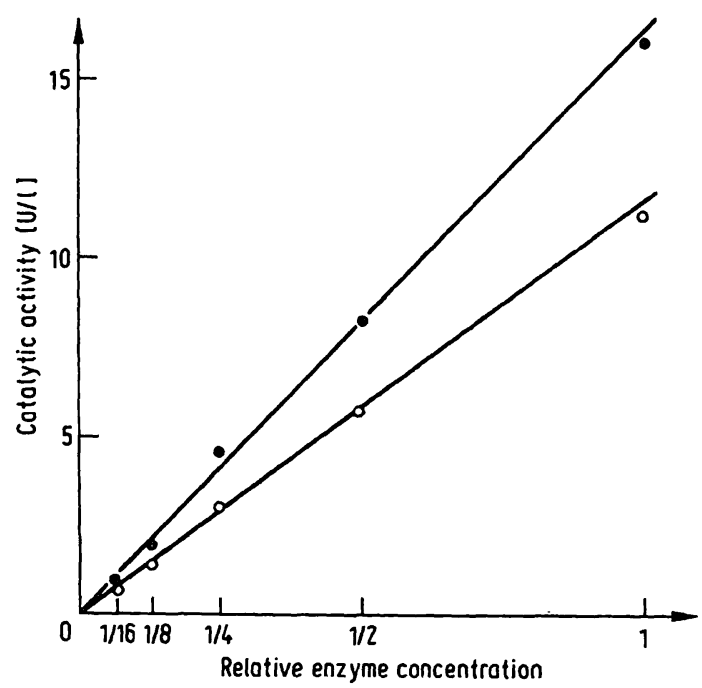

Fig. 4. Relationship between various enzyme concentrations and measured activities of total cholinesterase $(\bullet-\bullet)$ and acetylcholinesterase $(0-0)$. The supernatant from human colonic mucosal homogenate was diluted with known amounts of phosphate buffer. The undiluted sample was set as " 1 ".

\section{Disturbance of measurements in mucosal tissue by erythrocytes and serum}

The question arises concerning the quantity of pseudocholinesterase from serum and acetylcholinesterase from erythrocytes that might be contained in mucosal biopsy tissue and thus interfer with measurements: We found that 1 erythrocyte contains about $10^{-9} \mathrm{U}$ acetylcholinesterase activity. If one assumed that the biopsy particles consisted solely of erythrocytes their calculated enzyme activity would be about $3 \mathrm{U} / 1$ which is almost in the order of magnitude of enzyme activities usually measured $(5-20 \mathrm{U} / 1)$. On the other hand if erythrocytes were counted in the tissue homogenate, their number was relatively low: it was around $200 / \mathrm{mm}^{3}$ (range $50-450$ ). This would mean an acetylcholinesterase activity of about $0.2 \mathrm{U} / 1$, which is less than $5 \%$ of activities usually measured. Also after centrifugation, erythrocytes practically disappeared from the supernatant and were sedimented with the pellet. This indicates that interference in the measurements was even less, provided that erythrocytes were kept intact and not destroyed by homogenization, haemolysis or freezing.

Serum contains about $1 / 3$ of the cholinesterase activity found in packed erythrocytes. If one assumes that the quantities of serum and erythrocytes in tissue were about equal, interference from serum pseudocholinesterase should be even lower than from erythrocyte acetylcholinesterase. The inhibitor will also eliminate pseudocholinesterase activity in measurements of acetylcholinestèrase.

\section{Disturbances by drugs}

During routine endoscopy various drugs are employed, which may influence enzyme activities. We found that promethazine and triflupromazine, which are structurally related to lysivane, inhibited pseudocholinesterase only at concentrations higher than those encountered in therapy. Atropine, butylscopolamine, diazepam, pethidine and levallorphan did not influence enzyme activities.

\section{Quality of measurements}

In order to determine the precision of measurements the supernatant of colonic mucosal homogenate was assayed 12 times. Total cholinesterase activity was $1.8 \pm 0.01 \mathrm{U} / 1$. The CV was $6.1 \%$. Acetylcholinesterase was determined in another sample 12 times. Enzyme activity was $5.3 \pm 0.02 \mathrm{U} / \mathrm{l}$. The $\mathrm{CV}$ was $4.2 \%$.

Reproducibility was studied in the same sample on 12 different occasions with newly prepared reagents. Total cholinesterase measured $2.8 \pm 0.09 \mathrm{U} / 1$. The $\mathrm{CV}$ was $3.2 \%$. Acetylcholinesterase in another sample was $2.6 \pm 0.1 \mathrm{U} / 1$, the $\mathrm{CV}$ was $4.1 \%$.

\section{Results from normal biopsy specimens}

During routine colonoscopies and gastroscopies, biopsy particles were taken from various regions. If by histological classification they were judged to be "normal", enzyme activities were included in table 1 . We decided to refer measured enzyme activities to protein concentration rather than to wet-weight, since it proved to be difficult to rule out disturbances from evaporation.

Also it is customary to rêfer soluble intestinal enzymes to protein content, e.g. invertase (12). 


\section{ZNASSER}

calcium-Magnesium

\section{Meter}

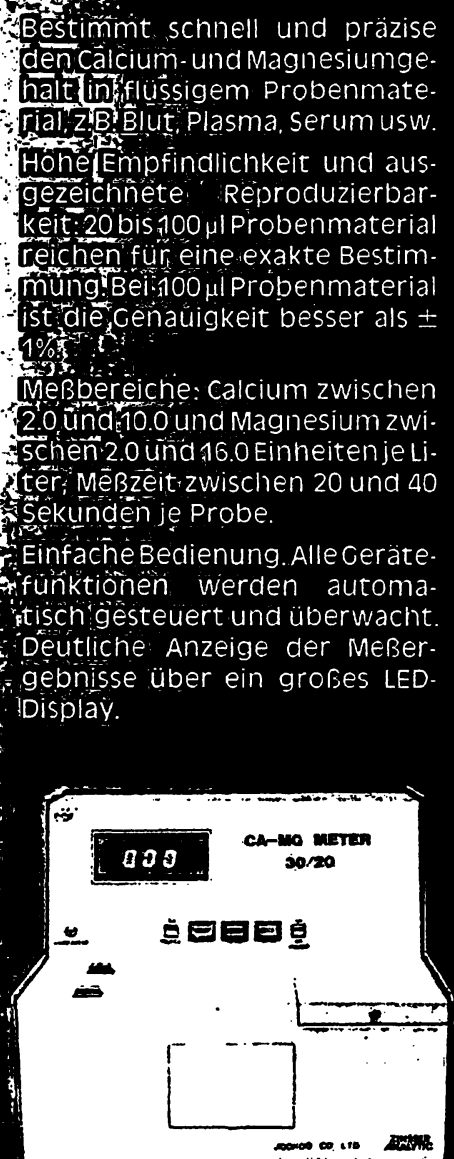

Mehr erfahren sie aus unseren Informationsunterlagen.

\section{Fettstoffwechsel- Diagnostik}

\section{nev] \\ Triglycenide 1. 1 N} vollenzypiatischer

Farbtest ohne frobentênwe

Erotesterin 2010
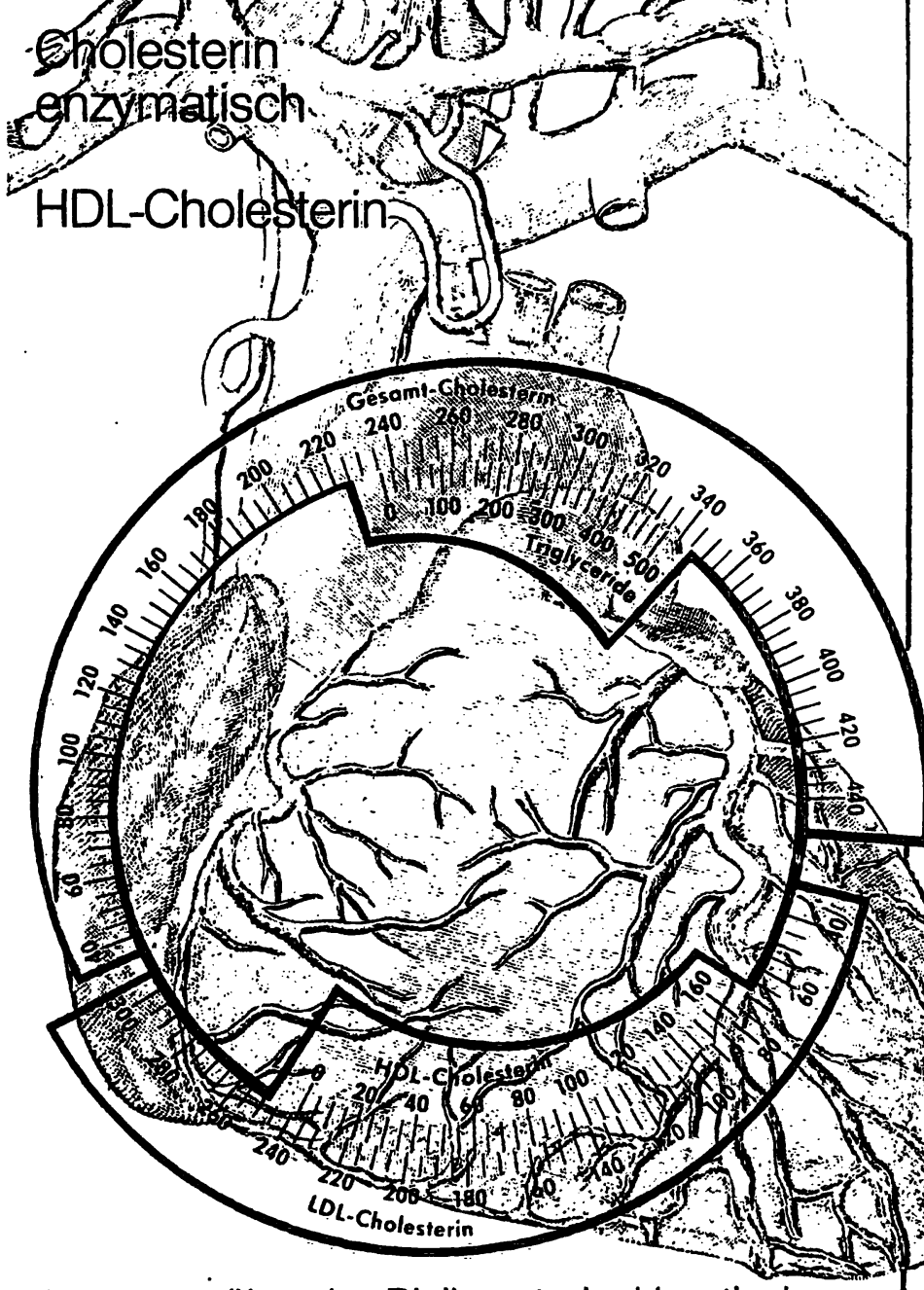

Aussagen über das Risiko arteriosklerotischer Gefäßerkrankungen sind durch die Bestimmung des Gesamtcholesterins und der Triglyceride im Serum möglich; darum sind diese beiden Bestimmungen als Basisprogramm der Lipiddiagnostik anzusehen. Die zusätzliche Bestimmung des HDLCholesterins erlaubt weitere fundierte diagnostische Aussagen.

\section{E. Merck, V Diag W}

Frankfurter Straße 250 D6100 Darmstadt 1 


\section{Küster-Thiel jetzt wieder lieferbar!}

102. Auflage 1982

0 völlig neu bearbeitet von Dr. Alfred Ruland

O SI-Einheiten

( größeres Format

(1) unentbehrlich seit eh und je!

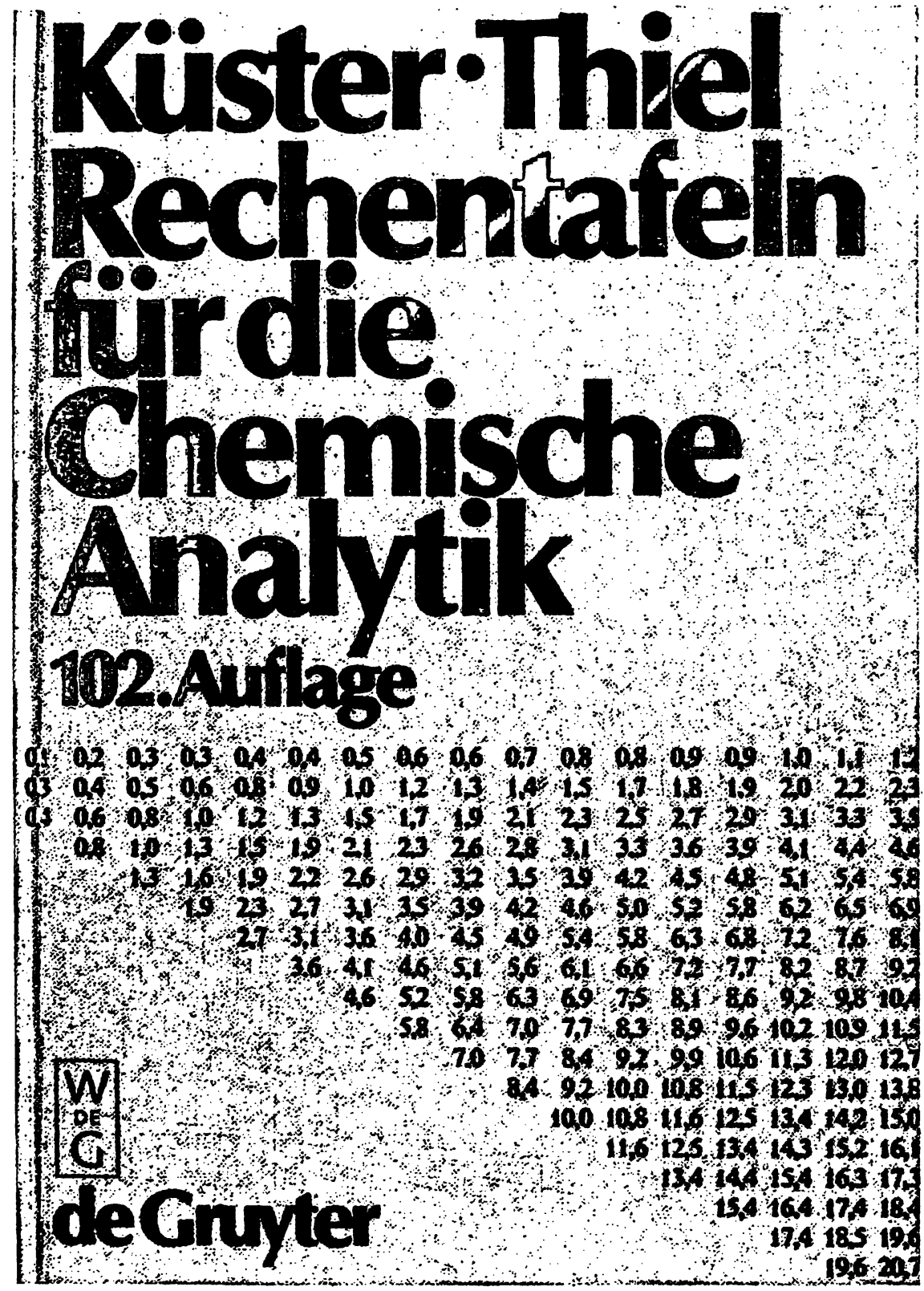

$17 \mathrm{~cm} \times 24 \mathrm{~cm}$. XII, 305 Seiten. Zahlreiche Tạbellen, teils zweifarbig. 1982 .

Fester Einband. DM 44,- ISB́N 311006653 X

\section{Walter de Gruyter · Berlin - New York}

Verlag Walter de Gruyter \& Co. · Genthiner Straße 13 · D-1000 Berlin 30 - Telefon (030) 2611341 
Tab. 1. Activities of total cholinesterases, acetylcholinesterase and pseudocholinesterase in normal human gastrointestinal mucosa. The material was obtained by forceps biopsy during routine endoscopies. Results are expressed per gram protein.

\begin{tabular}{lrllll}
\hline & $\mathrm{n}$ & $\begin{array}{l}\text { Cholin- } \\
\text { esterase }\end{array}$ & $\begin{array}{l}\text { Acetyl- } \\
\text { cholin- } \\
\text { esterase } \\
\text { (U/g) }\end{array}$ & $\begin{array}{l}\text { Pseudo- } \\
\text { cholin- } \\
\text { esterase } \\
\text { (U/g) }\end{array}$ & $\begin{array}{l}\text { Acetyl- } \\
\text { cholin- } \\
\text { esterase/ } \\
\text { Pseudo- } \\
\text { cholin- } \\
\text { esterase }\end{array}$ \\
\hline $\begin{array}{l}\text { Stomach } \\
\text { Fundus }\end{array}$ & 12 & $3.64 \pm 1.7$ & $2.47 \pm 1.1$ & $1.17 \pm 0.8$ & 2.11 \\
$\begin{array}{l}\text { Corpus } \\
\text { Antrum }\end{array}$ & 41 & $3.98 \pm 1.4$ & $2.96 \pm 1.2$ & $1.06 \pm 0.5$ & 2.79 \\
$\begin{array}{l}\text { Duodenum } \\
\text { Bulbus }\end{array}$ & 14 & $6.41 \pm 1.5$ & $2.90 \pm 1.5$ & $1.61 \pm 1.0$ & 1.80 \\
$\begin{array}{l}\text { Mid- } \\
\text { duodenum }\end{array}$ & 9 & $7.64 \pm 3.5$ & $5.45 \pm 3.0$ & $2.18 \pm 1.0$ & 2.50 \\
$\begin{array}{l}\text { Colon } \\
\begin{array}{l}\text { Coecum } \\
\text { Flexura } \\
\text { dextra }\end{array}\end{array}$ & 5 & $4.95 \pm 1.8$ & $2.40 \pm 1.0$ & $2.55 \pm 0.8$ & 0.94 \\
$\begin{array}{l}\text { Flexura } \\
\text { sinistra }\end{array}$ & 6 & $7.24 \pm 2.7$ & $3.46 \pm 0.9$ & $3.73 \pm 2.0$ & 0.93 \\
$\begin{array}{l}\text { C. sigmoi- } \\
\text { deum }\end{array}$ & 11 & $6.13 \pm 2.9$ & $3.48 \pm 1.8$ & $2.68 \pm 1.3$ & 1.30 \\
\begin{tabular}{l} 
Rectum \\
\hline
\end{tabular} & 7 & $8.08 \pm 2.5$ & $4.80 \pm 1.4$ & $3.28 \pm 1.4$ & 1.46 \\
\hline
\end{tabular}

In stomach, enzyme activities were in the same order of magnitude, if results from fundus, corpus and antrum were compared. There was, however, a tendency towards increase of pseudocholinesterase in the antrum. It has been demonstrated previously in various animals that gastrin producing G-cells are rich in pseudocholinesterase (2). From this finding it is tempting to speculate that the increase in pseudocholinesterase reflects the content of G-cells in antral mucosa.

In duodenum, enzyme activities were higher than in stomach. The increase was about equal in both enzymes, their ratio remaining close to 2 . This is in agreement with our findings in rabbits, which exhibited a continuous increase in enzyme activities in duodenum and jejunum, whereas there was a continuous decrease in ileum (unpublished results).

In colon, the content of pseudocholinesterase was higher than in stomach and duodenum, and the ratio to pseudo- cholinesterase was close to 1 . Also there was a continuous increase from coecum to rectum in both enzymes, but somewhat more in acetylcholinesterase.

The question arises as to how far these results have a physiological or clinical significance. Interpretation is hindered by the almost complete absence of information in the literature on the mucosal distribution of both enzymes. Moreover we do not know whether the soluble enzymes measured here are actually identical with total activities: from intestinal muscles of guinea-pigs only a fraction of the total enzyme activity could be extracted by homogenization (13).

Measurement of pseudocholinesterase and acetylcholinesterase has been of value for the diagnosis of M. Hirschsprung. It was shown that in rectal tissue there is an increase in acetylcholinesterase whereas pseudocholinesterase remains within normal range $(14,15)$. In this connection the demonstration of an abnormal molecular form of acetylcholinesterase in $M$. Hirschsprung should be mentioned (16). We have so far investigated 1 patient with this disease. In this case both acetylcholinesterase and pseudocholinesterase were grossly elevated, but the quantitative relationship of the enzymes was unchanged. This finding is'different from those reported in the literature $(14,15)$. On the other hand direct comparisons are difficult to make because the conditions of assay were different, e.g. total enzyme activity and acetylcholinesterase were measured at different $\mathrm{pH}$-values (7.9 vs. 7.4), which would affect readings considerably (fig. 2). Also enzyme activities were refered to wet weight rather than to protein content. This perhaps may account for the great variation of results reported from intestinal tissues other than rectum $(5,14)$.

Further investigations will be necessary to establish the value of acetylcholinesterase and pseudocholinesterase for other clinical problems, e.g. for the diagnosis of unclear constipation.

\section{Acknöwledgements}

Supported by Deutsche Forschungsgemeinschaft. This work contains parts of the doctoral thesis of cand. med. S. Bertl.

\section{References}

1. Koelle, E. S. \& Friedenwald, J. S. (1950) J. Pharmacol. 100, 180-191.

2. Carvalheira, A. F., Welsch, U. \& Pearse, A. G. E. (1968) Histochimie 14, $33-46$.

3. Garret, J. R., Howard, E. R. \& Nixon, H. H. (1969) Arch. Dis. Childh. 44, 406-417.

4. Shmerling, D. H. (1976) in Therapie der Krankheiten des Kindesalters (v. Harnack, G. A. ed.) p. 514-515, Springer. Verlag Berlin, Heidelberg, New York.
5. Dale, G., Bonham, J. R., Riley, K. W. A. \& Wagget, J. (1977) Clin. Chim. Acta 77, 407-413.

6. Augustinsson, K. B. (1955) J. Scand. Lab. Clin. Med. 7, $284-290$.

7. Augustinsson, K. B. (1963) in Handbuch der experimentellen Pharmakologie, Ergänzungsband XV (Eichler, O., Farah, A. \& Koelle, G. B. ed.) p. 90-128, Springer Verlag Berlin, Heidelberg, New York. 
8. Knedel, M. \& Böttger, R. (1967) Klin. Wochenschr. 45, 325-329.

9. Ellmann, G. L., Courtney, K. D., Andres Jr., V. \& Featherstone, R. M. (1961) Biochem. Pharmacol. 7, 88-95.

10. Weber, H. (1966) Dtsch. Med. Wochenschr. 91, 1927-1932.

11. Lowry, O. H., Rosebrough, N. J., Farr, A. L. \& Randall, R. I. (1951) J. Biol. Chem. 193, 265-275.

12. Hansen, W. \& Schreyer, D. (1981) J. Clin. Chem. Clin. Biochem. 19, 39-40.
13. Ambache, N., Freeman, M. A. \& Hobbinger, F. (1971) Biochem. Pharmacol. 20, 1123-1132.

14. Dale, G., Lowdon, P., Rangecroft, L. Bonham, J. R., Wagget, J. \& Scott, D. J. (1979) Lancet $I, 347-349$.

15. Patrick, W. J. A., Besley, G. T. N. \& Smith, J. J. (1980)

J. Clin. Pathol. 33, 336-343.

16. Bajgar̆, J. \& Hak, J. (1979) Clin. Chim. Acta 93, 93-95.

PD Dr. Werner E. Hañsen

2. Mediżinische Klinik rechts der Isar der TU München

Ismaninger Straße 22

D-8000 München 80 